\section{OPEN ACCESS}

International Journal of Applied Research in Social Sciences

P-ISSN: 2706-9176, E-ISSN: 2706-9184

Volume 3, Issue 4, P.No. 65-76, December, 2021

DOI: $10.51594 /$ ijarss.v3i4.270

Fair East Publishers

Journal Homepage: www.fepbl.com/index.php/ijarss

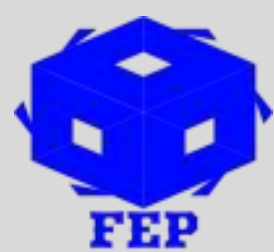

\title{
LAND RESOURCE DEVELOPMENT DECISIONS IN CENTRAL BUSINESS DISTRICT (CBD) OF THE TAMALE METROPOLIS IN GHANA
}

\author{
Justice Agyei Ampofo ${ }^{1}$ \\ ${ }^{1}$ University for Development Studies \\ Faculty of Natural Resources and Environment \\ Department of Environment and Sustainability Sciences, Nyankpala, Ghana
}

*Author: Justice Agyei Ampofo

Author Email: papajusty@gmail.com

Article Received: 08-11-21

Accepted: $29-11-21$

Published: 13-12-21

Licensing Details: Author retains the right of this article. The article is distributed under the terms of the Creative Commons Attribution-Non Commercial 4.0 License (http://www.creativecommons.org/licences/by-nc/4.0/) which permits non-commercial use, reproduction and distribution of the work without further permission provided the original work is attributed as specified on the Journal open access page.

\begin{abstract}
Tamale Metropolis have been experiencing a significant increase in economic activities especially with the influx of occupation, tertiary institutions, industrial explorations and usage of the town as the main transit route to other parts of the Northern Region and Ghana as a whole. Development of a Central Business District (CBD) has become very crucial for Tamale Metropolis as is seen in other parts of Ghana but this can best occur only depending on Land Resource Development Decisions (LRDD) taken by developers as every Central Business District backbone is on the built environment. This study explored the land resource development decisions in the Tamale Metropolis. The primary data for the study was obtained mainly through interviews with property owners within the Central Business District of Tamale Central. Existing literature both published and unpublished were also secured and reviewed. The study found out that there are more ripped for redevelopment properties than redeveloped properties within the Central Business District of Tamale Central with a source of funding being the major challenge towards redevelopment. Education, occupation and income are key things that were revealed to have a significant influence on the issue of redevelopment decisions within the Central Business District of Tamale. The study
\end{abstract}


recommends that there should be awareness creation on the various aspects of redevelopment to developers within the Tamale Metropolis by the Tamale Metropolitan Assembly, the introduction of a by-law on redevelopment within the CBD of Tamale by the Tamale Metropolitan Assembly Town and Country Planning Department and a special mortgage scheme by mortgage institutions/financial institutions in Ghana to support low-income developers in Tamale Metropolis to contribute to development and redevelopment of the housing industry thereby reducing the housing deficit of Ghana.

Keywords: Land, Resource, Development, Redevelopment, Redevelopment Decisions, Central Business District (CBD). Tamale Metropolis, Northern Region, Ghana.

\section{INTRODUCTION}

Land Resource Development Decisions in the Tamale Metropolis is considered as an investment for property owners. Property owners in Central Business District (CBD) envisage redevelopment opportunities and this call for redevelopment of their properties for their highest and best use (Attakora-Amaniampong, 2006; Ampofo, 2020). This is sustainable when the redevelopment meets both the present and future needs of the people. In most cities in developing economies, especially Ghana and specifically Tamale, redevelopment takes place mostly in the Central Business Districts (CBDs) where structures that are functionally and economically obsolescent are redeveloped for different use and these are mostly high rise buildings. Also, in developing economies cities, hardly will you find vacant land in the Central Business District.

The case of redevelopment within the Tamale Metropolis is however different and as observed, most existing structures in the Central Business District of Tamale are aged and due for redevelopment. Some vacant lands exist along the main road. The researcher's observation shows that the few ongoing and completed redevelopments within the Tamale Metropolis are mostly low-rise buildings which give rise to questions of sustainability as well as the highest and best use of land resources in the Central Business District. Thus land resource development and redevelopment decisions can both be private and public, whichever way the development is focused on, the goal should be beneficial to the entire society, but is this the case always?

Redevelopment is capital intensive and it calls proper timing so that a developer's capital does not get tied up with uncompleted projects and the source of financing such projects could either be Equity or Debt financing (Clauretie et al, 2003; Ampofo, 2020). Equity financing is less risky because there is no interest rate charged on funds and this can delay development since there might not be a free flow of funds from start to finish of the project. Debt capital can be borrowed from financial institutions with an interest rate charged on the amount borrowed (DeSousa, 2006). This is somehow risky but the developer will have funds from start to finish of the project. Whether with the use of Equity or Debt financing, the effort to keep the cost within bounds and realistic projections of expected cash flows of the operation is required by investors, which goes a long way to influence land resource redevelopment decisions.

With redevelopment, developers might also face problems due to planning regulation when their developments approach is not compatible with planning regulations (Greg Lewis, 2008; 
Ampofo, 2020). Notwithstanding, the background of the stakeholders involved which in this study are properties owners, can also influence redevelopment decisions. The traditional make-up, the educational level, occupation and ethnicity of these stakeholders can affect their decisions on social desirability and sustainability of redevelopment decisions. This study was conducted to explore the sustainability of land resource redevelopment decisions within the Tamale Central Business District.

\section{LITERATURE REVIEW}

\section{Concept of Land, Resource, Land Resource, Development and Decision}

Land is a delineable area of the earth's terrestrial surface, encompassing all attributes of the biosphere immediately above or below this surface including those of the near-surface climate the soil and terrain forms, the surface hydraulic (including shallow lakes, rivers, marshes, and swamps), the near-surface sediment layers and associated groundwater reserve, the plant and animal populations, the human settlement pattern and physical results of past and present human activity (Ampofo, 2020). Land as one of four basic categories of resources, or factors of production (the other three are labour, capital, and entrepreneurship).

Resource can be referred to as an economic or productive factor required for accomplishing an activity, or as means to undertake an enterprise and achieve desired outcome. Three most basic resources are land, labour, and capital; other resources include energy, entrepreneurship, information, expertise, management, and time. Again a resource is a source or supply from which benefit is produced with three main characteristics: utility, limited, availability and potential for depletion(Ampofo, 2020).

Land Resource comprises all naturally occurring resource whose supply is inherently fixed. Examples are any and all particular geographical locations, mineral deposits and even geostationary orbit locations and portions of the electromagnetic spectrum. Land Resource is broader and narrower than the term natural resource; broader because it includes a man-made improvement that are attach to land. Land resources when treated as an economic concept, is limited to surface resources together with the thin layer of subsurface and surface resources that people use in their daily lives (Sayas, 2006).

Development could be referred to as the process of economic and social transformation that is based on complex cultural and environmental factors and their interactions. It is the process of adding improvements to a parcel of land, such as grading, subdivisions, drainage, access, roads and utilities (Kasanga \& Kotey, 2001; David et al, 2006; Blessing Asamoah, 2010). Decision is the thought process of selecting a logical choice from the available options. When trying to make a good decision, a person must weigh the positives and negatives of each option, and consider all the alternatives. For effective decision making, a person must be able to forecast the outcome of each option as well and based on all these items, determine which option is the best for that particular situation (Donna, 2000; Isaac Bonsu Karikari, 2006).

\section{Development and Redevelopment in the Central Business District}

The Ghanaian land market is not based on available information but on speculations. A sites special attributes or unique location is mostly not factored into it price (George, 2006). The price differential for adjourning sites of similar size or characteristics could sometimes exceed $40 \%$ (Toraason, 2012). Land transactions in the country are organized outside the formal economy and none of the formal institutions keep record of them (Attakora-Amaniampong, 2006). There is huge ambiguity over the operations of Ghana land market. Land development 
precedes planning and planning laws are more often ignored (Ghana Housing Profile, 2010; Ampofo, 2020).

The land market in the some part of Tamale Central is highly underdeveloped; it is highly informal and the market for complete properties hardly exists. The land market in the Tamale Municipality is a market for bare and unserviced buildable lots. Infrastructure delivery follows development rather than development following infrastructure provision. This is due to the increase in building lots which have outpaced the supply of infrastructural facilities. The price of land in the Tamale Central varies with date of purchase and neighbourhood.

\section{METHODOLOGY}

\section{Research Design}

A qualitative research design was adopted for the study. Within Tamale Metropolis, the Central Business District of Tamale Central which was purposively selected. This is because the Tamale Central in the Northern Region of Ghana Central Business District is currently undergoing major infrastructural changes.

\section{Sources of Data}

With regards to sources of data collection under the study, both primary and secondary data were been relied upon. The secondary data were observed from books, journal, magazines, Ghana Statistical Services and newspaper, publication as well as internet sources. However, the primary source of data was obtained from the field survey.

\section{Population}

The target population consisted of all property developers within the Central Business District of Tamale who have been in the construction industry at Tamale in the Northern Region for more than ten (10) years. They were numbered 52.

Table 1

\begin{tabular}{cl}
\multicolumn{2}{c}{ Sample Size } \\
\hline Items & D \\
\hline Population & 52 \\
Sampled & 52 \\
\hline Source: Field Survey, 2021
\end{tabular}

\section{Sample Size and Sampling Technique}

Sampling units were the property owners (cooperation's, and individuals), while the sample size is the number of properties capture under the survey and pilot study of case study area which are 19 redevelopment, 31 ripped for redevelopment and 2 vacant land. The researcher adopted the maximal variation sampling to sample properties on some characteristics or description such as properties that were ripped for development, vacant lands and those ongoing and redeveloped properties. All the owners of the selected properties were also selected for the study.

\section{Data Collection Methods}

The following data collection methods and instruments were employed in this study. Observation was employed using observation guide which helped the researcher to record certain features of properties as they are and also to ascertain properties ripped for redevelopment. Face to face interviews using open ended questions and close ended questions to gather data on respondents' background, financial issues and challenges, if any, regarding land resource development decisions was also employed. 


\section{Data Analysis}

Thick descriptions were made of qualitative data which were critically examined well and presented in text and tables. Some of the qualitative data were coded and entered into Microsoft Excel and presented in tables and graphs to support the analysis and interpretation of data.

Table 2

\section{DISCUSSION OF RESULTS}

\begin{tabular}{lccccccccc} 
Occupation and Development Decisions \\
\cline { 2 - 2 } & \multicolumn{1}{c}{ Occupation } & Frequency & $(\%)$ & \multicolumn{7}{c}{ Land Resource Development Type } \\
\hline Self-employed & 29 & $\mathbf{5 6}$ & 11 & $\mathbf{3 7 . 9}$ & 17 & $\mathbf{5 8 . 6}$ & 1 & $\mathbf{3 . 4}$ \\
Government & 13 & $\mathbf{2 5}$ & 3 & $\mathbf{2 3 . 1}$ & 10 & $\mathbf{7 6 . 9}$ & 0 & $\mathbf{0 . 0}$ \\
Cooperation & 4 & $\mathbf{8}$ & 1 & $\mathbf{2 5 . 0}$ & 2 & $\mathbf{5 0 . 0}$ & 1 & $\mathbf{5 0 . 0}$ \\
Other & 6 & $\mathbf{1 2}$ & 4 & $\mathbf{6 6 . 7}$ & 2 & $\mathbf{3 3 . 3}$ & 0 & $\mathbf{0 . 0}$ \\
\hline \multicolumn{1}{c}{ Source: Field Survey, 2021}
\end{tabular}

From Table 2, it is revealed that majority (58.6\%) of self-employed respondents have their properties ripped for redevelopment compared with those who had redevelop. It was also realized that, majority of the government workers have their properties ripped compared with those who had redeveloped their properties. This implies that, among all the various occupation types, those involved in other works (private firms) had majority of their properties redeveloped. This further confirms the issue that the income range of self-employed developers who are the majority is not adequate to support the intensive capital required in land resource development. Again this explains why there are more ripped for redevelopment properties in the CBD compared to developed properties as majority of developers has inadequate income hence can't develop to meet highest and best use.

\section{Redeveloped Properties}

This data presentation is on properties that have been redeveloped from their existing state into new forms which includes all those who's use or type have been maintain or change. The study seeks to explore the decision that has influence such land resource development and weather they are sustainable. Nineteen (19) redeveloped properties are used in this analysis.

\section{Financing Redevelopment in CBD}

Land resource developments involve intensive capital investment which requires careful planning and assessment. The industry can be highly favourable or not and hence various source of funding are considered by developers with the major ones being debt funding (leverage) and equity funding. Leverage have to do with the use of loans/ borrowed money that comes with payment of interest in addition to the principal but mostly secured in terms of regularity and accessibility. Equity funding on the other hand are personal monies that are self-generated with no repayment and interest but depends on the personal income flow. Due to the high capital in land resource development, debt is considered a better option for most developers and hence the study seeks to explore into the source of funding by redevelopers within the $\mathrm{CBD}$ and the response is shown in the figure below. 


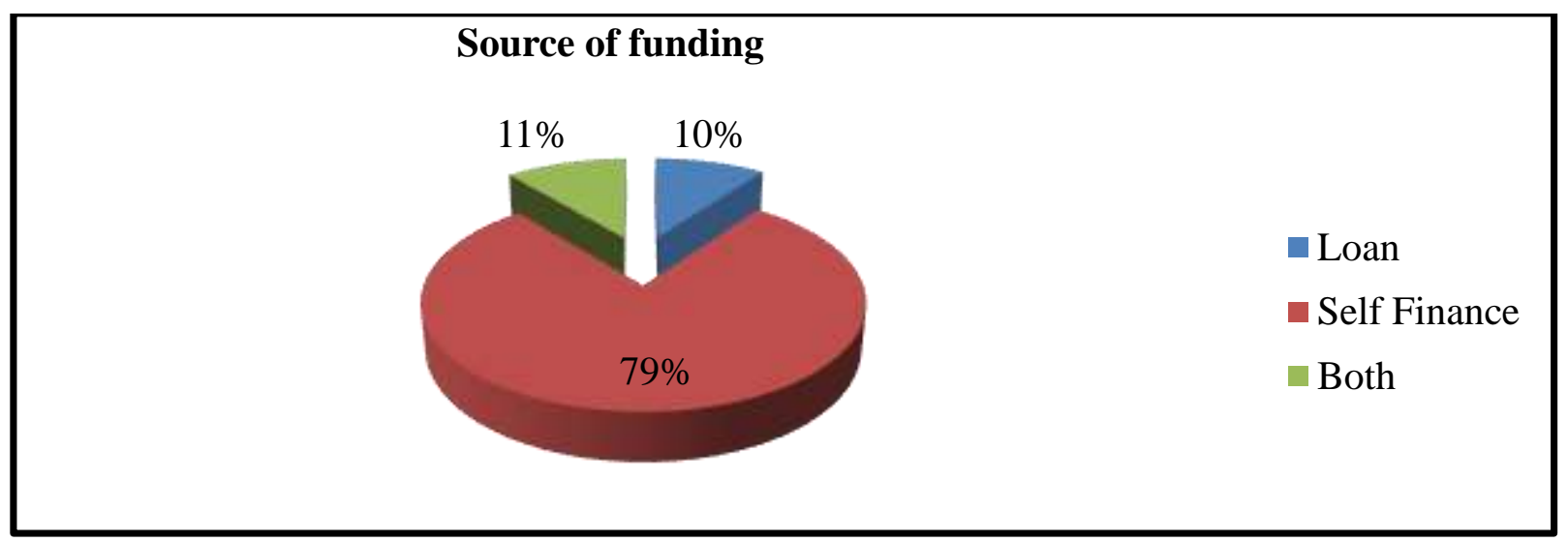

Figure 1: Funding of redevelopment projects

Source: Field Survey, 2021

It was released that, seventy nine percent (79\%) of the developers uses self-finance as their source of funding for redevelopment projects whiles eleven percent $(11 \%)$ relying on funds from financial institutions such as banks, credit unions etc. Ten percent (10\%) of the responses show that, both personal and financial institution funding is used together for the development of project.

This implies that, redeveloped properties funding are mainly dependent on personal income which does not fall in line with the general view of debt funding being the best. Hence the level and pace of development within the municipality are largely based on personal income a situation that have left most developers inability to meet the funding required for redevelopment hence more properties ripped for redevelopment within the CBD. Some developers indicated they don't have enough awareness about debt finance, others say they are not meeting the requirement for debt finance institutions whiles others shy away because of high interest and hence the current situation.

\section{Challenges to Redevelopment in Central Business District of Tamale}

Redevelopment involves various process and procedures including new design generation, permit acquisition, approval, demolition, etc. As a result of property ownership too, there may be the need for negotiation between partners before redevelopment is carried out and huge financing is as well required. These and many more can posse challenges to developers in quest to redevelop. In the light of this, the study seeks to explore into the possible challenges that developers face in the CBD of Tamale Central because such challenges have the tendency of affecting the development decisions of those involve. Figure 2 and 3 shows response to those with properties ripped for redevelopment and those who had redeveloped respectively.

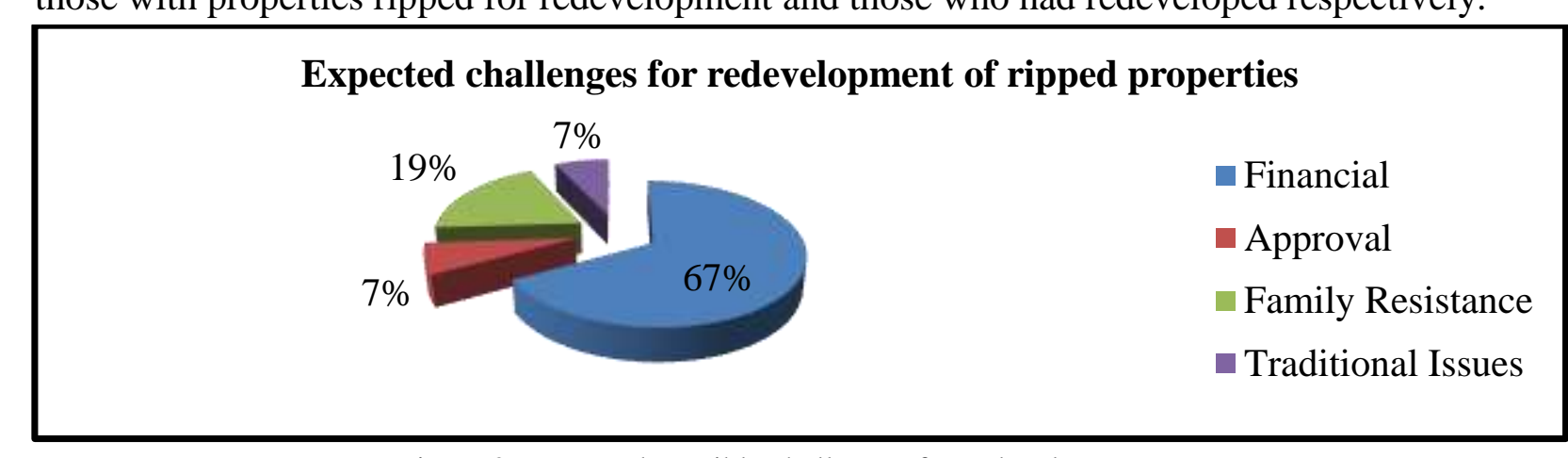

Figure 2: Expected possible challenges for redevelopment Source: Field Survey, 2021 


\section{Challenges associated with redeveloped properties}

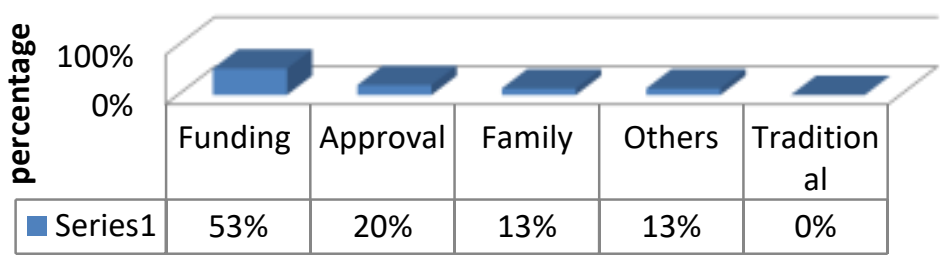

Figure 3: Challenges associated with redeveloped properties

Source: Field Survey, 2021

The distribution indicates that finance is the major challenge to both developers who had redeveloped and those yet to redevelop followed by approval/permit acquisition difficulty. With the issues of finance as a challenge, developers complain of inadequate income, not meeting requirement for loans (mortgages) and high interest on mortgages for those who meet requirement.

On approval difficulties, developers complain of long bureaucratic process and sometime extortion from officials. Even though seven percent (7\%) of developers who are yet to redevelop anticipates traditional issues to be a challenge, on the contrary none of the developers who had redeveloped encountered traditional challenges. This is an indication that the traditional administration welcomes redevelopment in the area without any conflicts. This realization is evidence that, developers face challenges such as finance, approval, and family resistance in redeveloping their properties and with finance being the major one confirms why there exist currently more ripped for redevelop properties in the CBD than developed properties.

\section{Properties Ripped for Redevelopment}

Properties ripped for development are those properties that their current state and location within the CBD do not provide the best economic valve base on the type of structure and the usage of such property. Examples of such properties are mud houses single story buildings located at the heart of the central business district CBD. In all thirty four (34) properties were identified as properties ripped for development and below is the breakdown of their analysis. From the field survey it was revealed that majority $(87 \%)$ of such properties identified developers accepted their properties were ripped for redevelopment whiles thirteen percent (13\%) of the respondents however did not accept their properties were ripped for redevelopment. The minority who did not accept their properties were ripped was on the bases that, their properties in their current state are providing them with economic returns that are satisfactory for them (that is the owners). On the other hand those who accepted were with the view that they are not satisfied with the current property economic performance and seek highest and best use.

On the issue of intention for redevelopment for those who accept that their properties were ripped for redevelopment, it was found that, even though eighty seven percent $(87 \%)$ of respondents accepted their properties were ripped for redevelopment it is seventy eight percent $(78 \%)$ who have the intention of redeveloping their existing properties. This implies that, twenty two percent $(22 \%)$ of respondents have no intention yet to redevelop. Their reasons are that redevelopment is faced with major challenges such as family restrictions 
where all family members have to come to agreement and contribute towards the redevelopment, approval difficulties and huge financial investments required. Hence with such developments, if no alternative strategies aside the decisions of the owners are adopted then such properties will not be redeveloped in the near future.

With the further probing to find out if the existing use of properties are beneficial enough or not, it was realized that, seventy one percent (71\%) don't see current/existing property to be beneficial enough whiles twenty nine percent (29\%) thinks otherwise. This is a confirmation of the issue about the majority of developers accepting that their properties were ripped for redevelopment and have the intention of redeveloping. This implies that even though the current redevelopment decision in the CBD is skewed towards ripped for redevelopment, the situation have the tendency of changing in the near future with majority of developers having intention of redeveloping.

\section{Property Type Interested in Redeveloping}

Generally CBDs are the major economic hub of towns with high economic activities. The general structure of CBDs is to provide the need infrastructure for the brisk economic activities expected. Land resource development activities within the CDB, should meet such high economic activities by providing the needed commercial infrastructural development hence making it social beneficial to the people. Tamale Central is a fast growing economic town in Ghana and the land resource redevelopment decisions are therefore expected to be towards providing such commercial development within the CBD to meet social desirability. Developers who have ripped for redevelopment properties with the intention of redeveloping were therefore asked the property type they have interest in redeveloping. This will reveal their redeployment decision and if they are socially desirable. Figure 4 below shows the response of developers.

\section{Property type interested in redeveloping within Tamale Central}

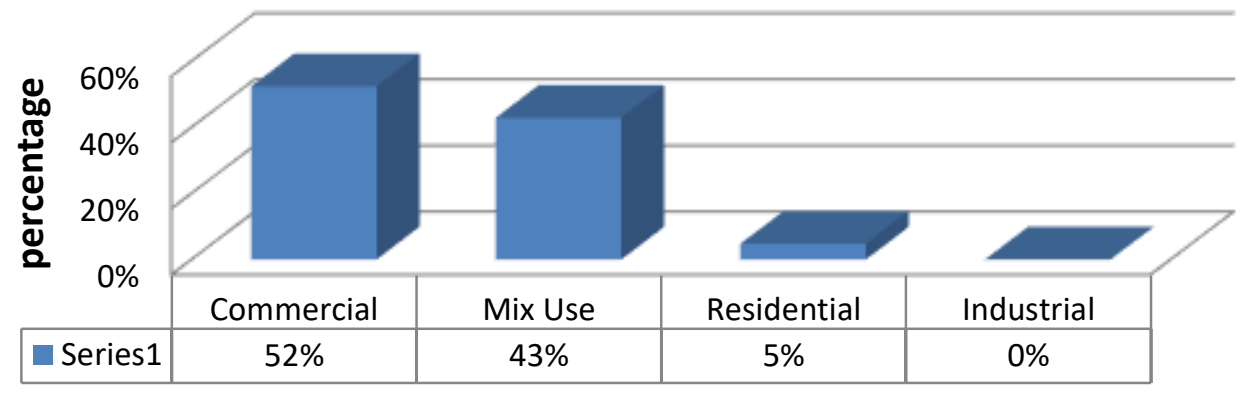

Figure 4: Property type interested in redeveloping Source: Field Survey, 2021

The outcome of the survey shown in the Figure 4 implies that, majority of developers want to develop commercial properties such as stores, trading centers, offices etc. and this is followed by those with the interest of developing mix use properties (combination of both commercial and residential). These finding therefore possibly suggest that, the decision to redevelop in the central business district of Tamale Metropolis is skewed toward commercial properties which affirms the development pattern of CBDs across the world. It also shows that even though the current situation of redevelopment in the CBD has more ripped for redevelopment, there is the intention of redevelopment decision of commercial property in the future. 


\section{SUMMARY OF FINDINGS, CONCLUSION AND RECOMMENDATIONS}

\section{Summary of Major Findings}

The study findings base on the analysis of the data is as follows:

- There are more ripped for redevelopment properties in the CBD of Tamale Central.

- Seventy one percent (71\%) of developers involved in redevelopment decision in Tamale Central were males, followed by twenty one percent $(21 \%)$ who were females and eight percent $(8 \%)$ were organizations with all of them being Ghanaian citizens.

- Seventy nine $(79 \%)$ of developers had some level of education while twenty one $(21 \%)$ were uneducated. Majority of the redeveloped properties belong to developers with education up to tertiary level.

- Self-employed respondents have their properties ripped for redevelopment compared with those who were employed by government.

- Sixty two percent (62\%) developers have income range of (101-1000) GH $\varnothing$ per month.

- Funding for redevelopment in the CBD mainly depends on equity funding which form seventy nine percent $(79 \%)$, followed by both equity and debt funding which form eleven percent $(11 \%)$ and ten percent $(10 \%)$ for only debt funding.

- The challenge to redevelopment are; finance sixty seven percent (67\%), approval nineteen percent (19\%) and seven percent (7\%) each for family resistance and others.

- The decision to redevelop in the central business district of Tamale Central is skewed toward commercial properties.

- The current redevelopment situation in the CBD of Tamale Central is skewed towards ripped for redevelopment, but has the tendency of changing in the near future with majority of developers having intention of redeveloping.

\section{Conclusion}

The conclusion to this study based on the findings are as follows; land resource redevelopment situation in the CBD of Tamale Central is that there are more properties with low economic use (ripped for redevelopment) compared to those that have high economic use (redeveloped). However, the majority of ripped for redevelopment property owners have intentions of redeveloping for the highest and best use in the future with commercial and mixuse (commercial and residential) properties being the main focus of such future redevelopment.

Males who are the indigence of Tamale Central Township dominate the redevelopment decisions within the CBD. However, there are more foreigners involved in land development with females also owning properties. This situation shows changing trends of ownership in land within the CBD where non-indigence control the usage of land. Education is key to survival in today's world with a majority of developers having some level of formal education is a good call. This can be a strong base for pursuing social desirable development and overcoming some of the challenges such as family and approval associated with redevelopment.

Again there are more self-employed involved in redevelopment decision making than any other occupation. However, the income of the majority of these developers fall within 100 $1000 \mathrm{GH} \notin$ which are not adequate to support the intensive capital involved in land resource 
development which explains why there are more ripped for redevelopment properties in the CBD of Tamale Central compared to developed properties

Redevelopment of land resources in the CBD of Tamale Central funding is mainly dependent on personal income (equity) which goes against the general view that debt funding is preferable to equity due to the high capital involved. This situation had left most developers inability to meet the funding required for redevelopment hence more properties were ripped for redevelopment within the CBD of Tamale Central compared to developed properties.

Developers within the CBD of Tamale Central by their dependence mainly on personal sources of finance (equity capital) to embark on land resource redevelopment projects with the view that it is less expensive compared to debt capital hence funding is a challenge to redevelopment. This situation is the main challenge of developers because equity capital for redevelopment is not adequate considering the income levels and hence there is the need for alternative sources of funding.

Furthermore, development permit approval along with family disputes are other challenges that confront developers within the CBD of Tamale which is contributing to the high number of ripped for redevelopment properties. Finally, the level of education, type of occupation, income levels, challenges of funding due to fear of loan and family issues are responsible for inadequate redeveloped properties in the CBD of Tamale Central.

\section{Recommendations}

Upon detailed discussion of the redevelopment situation of land resources within the CBD of Tamale Central the study strongly recommends the following;

1. Awareness creation

Since it was revealed that developers already have some insight about redevelopment, there is the need therefore for further awareness creation by all those who are concerned about landed properties development in general and redevelopment to be specific within the CBD of Tamale Central on the urgent need, how to get appropriate finance and approval for redevelopment. The organization that falls under this umbrella may include; Tamale Central Metropolitan Assembly, Town and Country Department and Property Owners Associations, Financial Institutions. This can be done through the Metropolitan Assembly in collaboration with Town and Country organizing seminars, radio programmes and outdoor forums in the communities for property owners to inform them on the merits of redeveloping to both owner and the society, the support that the assembly will give and how to go through the right procedure for approval free problems. Also, financial institutions should organize an outdoor forum to teach developers about the various debt finance options and how they can access them to their benefits.

2. Partnership Project Development

Still considering funding as the major challenge it is recommended that property owners should create a partnership with organizations interested in Build Operate and Transfer (BOT). This can be done by the developers going into agreement with such organizations; so that they will come and develop their properties with their resources and are allowed to operate it for a medium to long term to recoup their capital then the property is returned to their original owners.

3. Design of Special Mortgage Schemes 
It is also recommended that to solve the financial challenge, financial institutions should design a special low-income mortgage scheme that will meet the informal sector, which is the self-employed within the CBD to enable them to undertake a redevelopment decision.

4. Assembly introducing by-laws

In the situation where property owners should be compelled to redevelop in the interest of society, the Metropolitan Assembly can introduce laws on the redevelopment of properties within the CBD. This can be done through the planning authorities being ready to renew property permits only on condition that, property owners occupying properties within the CBD are read to redevelop to current planning standards.

\section{Acknowledgements}

The researcher wants to thank the editorial board of Fair East Publishers.

\section{Conflict of Interest Statement}

No conflict of interest has been declared by the author.

\section{Funding}

The researcher has not received any support for the publication of this paper.

\section{References}

Ampofo, A. J. (2020). Contributions of the hospitality industry (hotels) in the development of Wa. International Journal of Advanced Economics, 2(2), 21-38.

Ampofo, A. J. (2020). The nature of mortgage repayment plans in Ghana. Finance \& Accounting Research Journal, 2(3), 91-104.

Ampofo, A. J. (2020). Rural housing challenges in the Upper West Region of Ghana: A case study of Kulmasa. International Journal of Management \& Entrepreneurship Research, 2(4), 194-211.

Ampofo, A. J. (2020). Constraints factors to maintenance of government senior high school buildings in Wa Municipal. International Journal of Management \& Entrepreneurship Research, 2(3), 139-160.

Blessing Asamoah (2010), Urbanization and Changing Patterns of Urban Land use in Ghana: Policy and Planning Implications for Residential Land use in Kumasi.

Clauretie T.M., \& Sirmans G. S. (2003). Real estate finance: theory and practice ( $4^{\text {th }}$ ed.) South South Western Thompson Learning.

David, M. G, Norman, G. M., Jim, C., \& Piet, E. (2006). Commercial Real Estate Analysis and Investments ( $2^{\text {nd }}$ Edn.), South-Western, Thompson Learning.

DeSousa, C. A. (2006), Urban Brownfield redevelopment in Canada: The Role of Local Government. The Canadian Geographer, 50(3), 392-407.

Donna S. K., \& Shier. (2000 Issue), Brownfield Redevelopment: Opportunities and Constraints.

George, A. S. (2006), Towards the improvement of tenure security for the poor in ghana: some thoughts and observations, Ghana.

Elvis, A.E. (2006). Residential Development and Borrowing in Ghana: A Challenge for Banks and Private estate developers, Sweden 
Greg, L. (2008). Brown to Green: Sustainable Redevelopment of America's Brownfield Sites.

Isaac, B.K. (2006). Ghana's Land Administration Project (LAP) and Land Information Systems (LIS) Implementation: The Issues, Ghana

Kasanga, K., \& Kotey N. A. (2001). Land management in ghana: building on tradition and modernity, International Institute For Environment And Development, London.

Kwame, A.D. (1999). Utilization of urban residential land: a case study of Singapore, printed in Great Britain, Cities, 16(2), 93-101.

Sayas J.P. (2006). Urban sprawl in the peri-urban coastal zones of Athens. The Greek Review of Social Research, Special Issue, 121, 71-104.

Stuart Toraason, PE, LEED AP (April 04, 2012), Facing the Challenges of Redevelopment. 